\title{
The Impact of Curriculum and Instructional Choices on Undergraduate Students in Introductory Geology
}

\author{
Christopher Roemmele ${ }^{1}$ \\ ${ }^{1}$ West Chester University, USA \\ Correspondence: Christopher Roemmele, West Chester University, USA.
}

Received: July 23, 2019

Accepted: August 19, 2019

Online Published: August 28, 2019

doi:10.5430/irhe.v4n3p17

URL: https://doi.org/10.5430/irhe.v4n3p17

\begin{abstract}
This research investigated the impact of an introductory geology class on undergraduate students' attitudes toward and conceptual understanding of geology. The purpose was to identify students' geologic blindness, a construct of disinterest, disdain, and unawareness of geology, geologic processes, and their relationship to humans, by assessing students' views on curricular and pedagogical choices. A convergent parallel mixed-methods research design was conducted. The participants consisted of 289 students enrolled over two semesters in an introductory geology class for non-majors. Specific to content and instruction, students found the format of rock and mineral labs and exams difficult and in need of change. They expressed positive attitudes about the hands-on, collaborative nature of these labs, and observation skills to perform them. Curriculum topics judged more interesting were deemed less difficult to understand, and vice versa, and that there was general understanding of geology's broader themes of tectonics and time. Open-ended responses from participants, and interviews with key informants provided further evidence for these results. Students indicated that explicit instruction on the topic relevance, cross-topic connections, and on-going assessment and the use of a variety of visualizations and collaborative work would help to improve understanding and attitudes. The results provide insight into ways to improve introductory geology courses by addressing geologic blindness.
\end{abstract}

Keywords: geologic blindness, geoscience education, curriculum, instruction, introductory geology, student affect, attitudes, conceptual understanding

\section{Introduction}

Young children are often fascinated with dinosaurs and their fossils. Some children may have rock collections that stay with them to adulthood for nostalgia or sentimental reasons. The media focuses its attention on a devastating attention-catching earthquake or flood. Yet American university and secondary students may struggle to find geology interesting or meaningful. Learning geology is frequently met with ambivalence, apathy, scorn (DeLaughter, Stein, Stein, \& Bain, 1998; Almberg, 2011), or worse, geology is seen as an easier and less relevant science, or as an irrelevant academic discipline and simply as a general education course requirement.

Regardless of where and when any pre- or mis-conceptions of geology emerged, the instructor's challenge is to lead students, many of whom are non-science majors, out of this disconnect, and to provide students with a new perspective with which they may view all that geology comprises. This means instructors should treat the introductory course as seriously as they would an upper level undergraduate or graduate course. Geoscience educators must be more critically aware and get a better and deeper sense of our students' attitudes and perceived understandings of geology. What do they like to learn and how do they want the class structured to enhance their learning experience so that geology - or any science - become a living breathing entity that students are aware of and see a meaningful portion of their lives? Whether attention is paid to course content, the delivery, the workload, or the activities, the subtle changes that can be made to any of a number of aspects of an introductory geology course has the potential to benefit the students in terms of learning and understanding the material, finding a connection with it, and even pursuance of future study.

Many students may be "geologically blind" when they walk into an introductory geology or earth science classroom on the first day of school. The concept "geologic blindness" derives from the term "plant blindness," which describes a condition of students with low interest in and a nonchalant attitude toward plants (Wandersee \& Schussler, 1999, Wandersee, Clary, \& Guzman, 2006). The same phenomenon can apply to geology. I adapted and reshaped the indices of plant blindness to define geologic blindness: 
- $\quad$ Lack of acknowledgement of the rocks, structures, and landscape within one's locality or environment, and that geology is a backdrop for our existence.

- Inability to acknowledge or notice the importance and significance of geology in human everyday life.

- Indifference and insensitivity towards appreciating purely aesthetic aspects of geology.

- $\quad$ Failure to recognize the uniqueness of certain geologic features.

- Inability to place importance on the impact of the geologic world on humans—and vice versa — and our stewardship of the Earth.

- $\quad$ Lack of hands-on or in-situ experience with rocks and other geological features.

- Unawareness of the key cycles in geology and the role they and geologic time play in our existence.

Learners of all ages are often "blind" to what is in front of them, especially when the objects are immobile or deemed passive like plants or in this instance for geology - rocks and landscapes. Students are much less likely to encounter cataclysms like earthquakes and volcanic eruptions even though those events are more likely to get the attention in the news. Yet the geology that students most frequently encounter in their lives are those geological events that are or seem less enticing: rivers flowing and changing course by redistributing sediments; minerals and rocks weathering; and rock formations defining landscapes. Combined with a lack of exposure and instruction, common misconceptions about geology lead students to adopt attitudes that mimic views about plants. That is, rocks, rivers, and landscapes are wordless, emotionless, and therefore utilitarian (Schneekloth, 1989; Tunnicliffe, 2001).

A low percentage of American high schools offer either an earth science or geology course, and the annual percentage of students who actually take a secondary earth science class not much higher (Lewis \& Baker, 2010; Blank, Langesen, \& Petermann, 2007), another problem arises with geology and earth science treated as an aside from the "real" sciences in these formative K-12 years. This practice may have created the false impression to students, who by the time they are in a post-secondary introductory geology course, that geology and all earth sciences are easier than other scientific disciplines. Or, they will not be challenged by the material (Gilbert et al, 2012), or they are simply unaware that geology is a science that is present around and relevant to them every day.

There is a substantial quantity of literature about college students taking introductory science classes centered on their attitudes, motivation and self-efficacy. However, there is far less research on introductory geoscience classes, although studying affective behaviors toward geology and learning geology share a common thread of this geoscience education research as well. In order to better understand these attitudes and perceptions of geology held by students in an introductory geology class, the influence of course scope and sequence, student preference for the topics and activities and impact they may have on student learning and understanding of geology may be a future source of geoscience education research. Additionally, this research is mixed-methods, which converge the quantitative and qualitative data and correlates them for deeper meaning and insights into answering the research questions. Mixed-methods research is utilized more in geoscience education research, but has not been a means to investigate the relationship of student affect and understanding in introductory geology as they relate to the curriculum and instruction. Examination of the specific topics, the instructional technique and learning activities that instigates and initiates attitude changes may be important to instructors who teach introductory classes in scaffolding instruction and developing a curriculum. By determining what facets of an introductory geology curriculum and course may instigate attitudinal changes toward learning and understanding geology, then mitigating and eliminating geological blindness may be easier to accomplish.

The questions which guided this study were: (1) What are students' attitudes toward geology and how does that influence their learning and understanding of geology? (2) What are students' perceived understandings of geology and how does that influence their attitudes toward learning and understanding geology? (3) What aspects of the instruction and curriculum of an introductory geology course influence students' understanding and attitudes toward geology and why?

This paper reports on the results of the study as they pertain to the third question.

\section{Background}

Existing literature and research about students enrolled in an introductory geology class often centers on two constructs: instructional and classroom management strategies and student affect and how it is measured or changes throughout the classroom experience. Literature detailing pedagogy describes the development and implementation of new techniques or activities, which may often take place at an individual university, and the change or improvement (or lack) of conceptual understanding and academic performance based on said changes to classroom instruction, structure, and learning activities. There have been fewer studies in geoscience education literature describing another particular 
arm of introductory geology courses: the scope of the class (the selection and number of content topics) and the sequence in which these topics are presented.

Since the beginning of the millenium, geoscience education research has maintained that introductory geology classes shift toward a more student-centered design, with more focus given to the content, skills, and the nature of science of geology. Integration of effective learning strategies (collaborative experiences, metacognitive reflections, authentic assessment, inquiry and problem-based learning) must be infused throughout a course to ensure and improve student learning and understanding (Harris, 2002). Because introductory geology students may often have weak science and earth science backgrounds, they often struggle to ascertain what geology is all about and what the job of a geologist encompasses (Almberg, 2011). Thus, revisions and redesign of the structure and delivery of the material and teaching format may be necessary to ensure students leave introductory geology having met required learning targets and demonstrate improved critical thinking and scientific practice skills. These modifications to course delivery to promote more active learning include electronic response systems to promote formative assessment (McConnell et al, 2006), improve class attendance and students' performance on exams, and attitudes toward learning science (Greer \& Heaney, 2004; Pun, 2010; Novak, 2011). Other changes that improve student performance and understanding of geology at the introductory level include using short story narratives (Vanderlinden, 2007)], performing critical reading exercises and analyzing student-derived concept maps (Mattietti, Peters, \& Verardo, 2009; Berry, 2013) examining forms of visualizations to improve spatial reasoning ( 2 or 3 dimensional images, or web-based or physical models) (Durbin, 2002; Johnson \& Reynolds, 2005; Del Costello \& Cooke, 2008; McNeal, Spry, Mitra, \& Tipton, 2014), using Google Earth and Virtual Reality (VR) to provide meaning and relevance of local and regional geology (Monet \& Greene, 2012), and giving collaborative and multi-stage exams (Eaton, 2009; Knierim, Turner, \& Davis, 2015). These opportunities provide the opportunity for students to become more engaged in class, their work, and their own ideas and values.

Setting a curriculum for an introductory geology course and making pedagogical decisions with respect to the scope (the number and particular selection of topics) and sequence would seem to be an integral part of maintaining student engagement and motivation. However, there is not extensive research on this aspect of instruction on student understanding of geology or student affective behavior. Literature is also scarce regarding course scope and sequence as it pertains to introductory geology courses, and whether or not the number of topics, a macro to micro learning progression (or vice versa), or case-study approach is pedagogically effective to student achievement. Agreement on a standard set of topics in geology, constructed by geoscience instructors via participation in national workshops and conferences does not appear to be reached by a large consensus of instructors. The American Geosciences Institute (AGI) has put forth a wide range of basic competencies taken from the National Association of State Boards of Geology Task Analysis Survey (Houlton \& Ricci, 2015), although these are more geared for undergraduate majors and not necessarily the expectations and objectives that students should reach by the end of an introductory geology course. Suggested approaches to do this include utilizing a national news search engine for topic selection (Jach, Cervato, \& Ridky, 2009) of current issues to earth science topics, and a consensus-based checklist of questions that focus on the topic and its processes to help develop and encourage students' mental models (Mathison, 1989).

With regard to course topic sequence in the geosciences, a singular study by Hippensteel and Schwimmer (2004) analyzed 133 syllabi of introductory geology courses and 16 commonly used introductory geology textbooks to ascertain the most common order of topics. The sequencing of five topics (minerals, rocks, volcanoes, earthquakes, plate tectonics) and their presentation during the semester (based on the syllabi) were documented. Similarly, the texts used by each instructor were also catalogued based on the sequence of the above five topics. Two distinct approaches were noted. The majority of schools utilized the "traditional" approach (minerals first, tectonics last) - thus a microto-macro scheme. Fewer courses had adopted a "recent" methodology (tectonics first) which may be viewed as a macro-to-micro format. However, no consideration was given to student preference or how the course structure impacted learning and understanding or affective behavior. The rationale behind curriculum choices as expressed by the instructors was not investigated either. The geoscience community needs to attain consensus regarding not only what the most important and significant concepts that should be taught in an introductory course, but present them in a logical sequence that builds and maintains student interest and motivation, as well as develops the relationships across the topics as they are covered. This includes teaching using case-based (as often done in business, law, and medical school classes) as Goldsmith (2011) recounts, place-based (Hammersley, Levine, Cornwell, Kusnick, \& Hausback, 2012), or systems approach (Atkin, Jorgensen, \& Zeiler, 2005). More research regarding how this specific factor of course revision may influence student affect and academic performance may be useful to further define the curriculum. Establishing a standard set of learning progressions for all geological concepts will also be useful. This may be a future area of research for the geoscience education community to identify consensus and trends on these issues and to 
explore if there are indeed correlations and relationships between and amongst student understanding, performance, and affective behavior.

\section{Methodology and Methods}

\subsection{Methodology}

This mixed-methods study was conducted at a large, midwestern land grant research-based university over two semesters of an academic year. Grounded in pragmatism, this approach allowed the researcher to build knowledge and understanding of introductory geology students by employing a "what works" attitude. The diversity and compatibility of utilizing both qualitative and quantitative methods and the practical application of the research guide the research and the methods themselves (Creswell \& Clark, 2007). A convergent parallel mixed-methods design was used for this research by collecting quantitative and qualitative data during the same phase of research (repeated in a subsequent semester), and then combined into an overall interpretation. This method was advantageous to this study because the strengths of quantitative and qualitative data to complement each other.

\subsection{Quantitative Procedures}

Pre- and post- surveys were developed and distributed in order to collect a range of information from the participants in the introductory geology class. The survey included questions about basic demographic, educational background and item clusters relating to student attitudes and learning preferences. These items were adapted from other well-known survey instruments with established validity and reliability (Motivated Strategies for Learning Questionnaire (MSLQ) (Pintich, 1991), Colorado Learning Attitudes about Science Survey (C-LASS)(Adams et al, 2006), Chemistry Attitudes and Experiences Questionnaire (Dalgety, Coll, \& Jones, 2003), Changes in Attitudes about the Relevance of Science (Seigel \& Ranney, 2003), Biology Self-Efficacy Scale (Baldwin, Ebert-May, \& Burns, 1999), and the Self-Efficacy and Outcome Expectancy Scale (Riggs, Warka, Babasa, Betancourt, \& Hooker, 1994). Modifications were made to items by substituting the word "geology" in place of words like "biology," "chemistry," and "science," so that they would remain relevant to the function of the survey instrument. This ensured maintenance of the validity of the survey because validity itself does not lie in the survey but in its use and interpretation of its results (Douglas \& Purzar, 2015). The items were all scored on a 5-point Likert scale. Additionally, there were a series of course content-based items designed to measure student learning of content knowledge. These items were based on the course curriculum and were adapted from the Geoscience Concept Inventory (GCI)[Geoscience Concept Inventory, 2014; Libarkin, Anderson, Deeds, \& Callen, 2006).

Post-survey items were similar to the pre-survey items so that match-pairs statistical analysis could be effectively performed to monitor any changes that may have occurred throughout the semester-long course. All quantitative data was analyzed using Statistical Package for the Social Sciences (SPSS). Matched-pairs t-tests were used to determine significant changes over the students' time in the course. Although the changes between pre- and post-survey on an item or items may be statistically significant using the matched-pair t-test, the meaningfulness of an item's result depended on the individual item itself and the context in which it existed. This meant whether or not it can be triangulated with other quantitative or qualitative data and converged with other data to be integrated as one of the findings for this study. A statistically significant change on an item by the key informants was compared to the full participant cohorts and other qualitative data to identify convergence. If there was triangulation from other data sources, then it was considered a meaningful result. This was evaluated on an item by item case as they pertained to the research questions.

For multiple choice items, a McNemar test was performed, and for the item clusters (attitudes, perceived understanding, instructional preferences), a 1-sample t-test was performed to determine the overall change of the cluster mean from pre- to post- that pertained to the answering the specific research questions. There were several items inquiring student input about curricular. These items required students to rank order items, and as such they were not a part of the 1 -sample t-testing due to other effects on those remaining options and where they were ranked. Other descriptive statistical analysis (median and mode) was employed to ascertain how participants felt about particular curricular choices and class and lab activities.

\subsection{Qualitative Procedures}

Two rounds of semi-structured interviews with the key informants were performed, the first in the first week of the semester, and the second one during the last week. Student responses frequently led to exploratory questions to further elaborate and provide deeper insight into their perceptions and attitudes of learning geology. The interviews were recorded, transcribed, and coded, and then read, reviewed, and coded by three other raters using nVivo software and hard copies for reliability. Interrater reliability ranged from $80 \%$ to $93 \%$. 
Post-surveys included several open-ended free response items which were categorized and coded with emergent themes. These themes were correlated with those that were produced from key informant interviews. The responses about curriculum and instruction and how they impacted student learning and understanding provided greater depth in answering the research questions. Free-response items were also checked by raters for reliability. Lab observation and conversation field notes were memoed and compared with similar interview and free-response item themes to further cement trends in students' attitudes and understanding.

\subsection{Mixed Methods}

Being a mixed methods study, quantitative and qualitative methods and data were integrated and analyzed in order to detect whether or not students' experience in the course changed their understanding and attitudes. Mixing helped identify course aspects and factors that were most impactful and meaningful, and provided keys to the existence and extent of geologic blindness amongst the participants. Analysis of interviews, open-ended item responses, lab observations and conversations, and all quantitative data helped to confirm process validity from corroborating themes across both research domains. This paper presents findings that pertained to aspects of the course related to curricular aspects of the course and how those played into geologic blindness and the potential to emerge from that blindness.

\subsection{Participants}

Student participants ( $\mathrm{n}=289$ ) were all undergraduates enrolled in the introductory physical geology course targeted for non-majors at a large, midwestern, land-grant, research-based university. For the duration of the study, the course instructor, the teaching assistants, the course syllabus and lab curriculum and activities, and course exams were the same both semesters, as was the syllabus and curriculum of the course.

Participants had great diversity in their respective major areas, a third of whom were computer science majors. The majority of students in the course both semesters were male, and spring semester contained a larger percentage of first-year students (Tables 1a \& 1b). A third of the students had never had an earth science class in either middle or high school (the largest of all sciences excluding environmental science) and for more than two-thirds of the students, this course was either their first or second science course. The 18 key informants mimicked the large group encompassing a diverse set of backgrounds, declared majors, and science coursework.

Tables 1a \& 1b. Class standing and declared majors of the participants

\begin{tabular}{ccc}
\hline Class Standing & Fall Semester $(\mathbf{n = 1 4 6})$ & Spring Semester (n=143) \\
\hline Freshman & $5(3 \%)$ & $65(45 \%)$ \\
\hline Sophomore & $52(36 \%)$ & $30(21 \%)$ \\
\hline Junior & $52(36 \%)$ & $30(21 \%)$ \\
\hline Senior & $37(25 \%)$ & $18(13 \%)$ \\
\hline Major Classification & & Spring Semester \\
\hline Physical Sciences & $2(1 \%)$ & $6(4 \%)$ \\
\hline Life Sciences/Agriculture & $8(5 \%)$ & $6(4 \%)$ \\
\hline Engineering & $11(7 \%)$ & $4(3 \%)$ \\
\hline Computers/Technology & $49(33 \%)$ & $50(35 \%)$ \\
\hline Mathematics/Statistics & $13(9 \%)$ & $31(22 \%)$ \\
\hline Humanities/Liberal Arts & $19(13 \%)$ & 0 \\
\hline Education & $3(2 \%)$ & $24(17 \%)$ \\
\hline Business/Finance/Management & $19(13 \%)$ & $9(6 \%)$ \\
\hline Visual/Communication Arts & $12(8 \%)$ & $8(6 \%)$ \\
\hline Other & $11(7 \%)$ & \\
\hline
\end{tabular}




\section{Results}

\subsection{Curricular and Lab Aspects}

To ascertain how topic choice influences students' affect, participants rank ordered 10 introductory geology topics based on their interest in learning about the topic (1=most interest, 10=least interest) and in terms of difficulty in understanding (1=least difficult, 10=most difficult or hardest). The 10 topics, most of which were part of the curriculum of the course they were taking, were chosen based on their appearance frequency in a document analysis of 75 introductory geology syllabi from a variety of post-secondary institutions (four-year universities and liberal arts colleges, and two-year community and county colleges).

Based on statistically significant changes in the mean between the pre- and post-surveys, four topics - geologic time, plate tectonics, volcanoes, and rivers/floods - showed significant gains in interest. These same four topics also had significant positive gains in terms of them being perceived as easier to understand. Four topics, earthquakes, glaciers, groundwater, and minerals, experienced significant reductions in their mean, meaning that participants felt that these topics were less interesting to learn about. Participants rated the same four topics as more difficult to understand, as these topics showed a significant negative shift in their mean ranking between pre- and post-survey (see Table 2a and b).

Table 2a. Means and significance of rank order of topic interest

\begin{tabular}{|c|c|c|c|}
\hline ITEM & $\begin{array}{c}\text { Combined Pre } \\
(n=228)\end{array}$ & $\begin{array}{c}\text { Combined Post } \\
(n=228)\end{array}$ & Combined Significance \\
\hline Earthquakes & 3.61 & 4.37 & $0.000 * * *$ \\
\hline $\begin{array}{l}\text { Key Informants } \\
\quad(\mathrm{n}=9,9,18)\end{array}$ & 5.50 & 5.77 & 0.544 \\
\hline Geologic Time & 5.39 & 4.16 & $0.002 * *$ \\
\hline $\begin{array}{l}\text { Key Informants } \\
(\mathrm{n}=9,9,18)\end{array}$ & 4.37 & 3.41 & $0.035^{*}$ \\
\hline Glaciers & 4.46 & 5.29 & $0.000 * * *$ \\
\hline $\begin{array}{l}\text { Key Informants } \\
(\mathrm{n}=9,9,18)\end{array}$ & 4.12 & 6.71 & $0.000 * * *$ \\
\hline Groundwater & 6.05 & 6.46 & $0.037^{*}$ \\
\hline $\begin{array}{l}\text { Key Informants } \\
\quad(\mathrm{n}=9,9,18)\end{array}$ & 6.47 & 6.57 & 0.900 \\
\hline Minerals & 6.02 & 7.01 & $0.000 * * *$ \\
\hline $\begin{array}{l}\text { Key Informants } \\
(\mathrm{n}=9,9,18)\end{array}$ & 4.41 & 5.29 & 0.401 \\
\hline Plate Tectonics & 6.31 & 4.80 & $0.004 *$ \\
\hline $\begin{array}{l}\text { Key Informants } \\
(\mathrm{n}=9,9,18)\end{array}$ & 7.12 & 6.06 & 0.271 \\
\hline Rivers-Flooding & 5.58 & 4.88 & $0.000 * * *$ \\
\hline $\begin{array}{l}\text { Key Informants } \\
\quad(n=9,9,18)\end{array}$ & 6.59 & 5.88 & 0.251 \\
\hline Rocks-Rock Cycle & 7.21 & 7.11 & 0.626 \\
\hline $\begin{array}{l}\text { Key Informants } \\
(\mathrm{n}=9,9,18)\end{array}$ & 6.47 & 6.18 & 0.726 \\
\hline Volcanoes & 3.91 & 3.12 & $0.000 * * *$ \\
\hline $\begin{array}{l}\text { Key Informants } \\
\quad(\mathrm{n}=9,9,18)\end{array}$ & 4.06 & 3.94 & 0.854 \\
\hline Weathering-Erosion & 6.44 & 6.29 & 0.497 \\
\hline $\begin{array}{l}\text { Key Informants } \\
\quad(\mathrm{n}=9,9,18)\end{array}$ & 6.24 & 5.76 & 0.470 \\
\hline
\end{tabular}


Table 2b. Means and significance of rank order of topic difficulty in understanding

\begin{tabular}{|c|c|c|c|}
\hline ITEM & $\begin{array}{c}\text { Combined Pre } \\
(\mathbf{n}=228)\end{array}$ & $\begin{array}{c}\text { Combined Post } \\
(n=228)\end{array}$ & Combined Significance \\
\hline Earthquakes & 4.92 & 5.88 & $0.001 * * *$ \\
\hline $\begin{array}{l}\text { Key Informants } \\
\quad(n=9,9,18)\end{array}$ & 6.69 & 5.13 & 0.106 \\
\hline Geologic Time & 4.95 & 4.38 & $0.042 *$ \\
\hline $\begin{array}{l}\text { Key Informants } \\
\quad(\mathrm{n}=9,9,18)\end{array}$ & 4.38 & 3.31 & 0.139 \\
\hline Glaciers & 5.57 & 6.50 & $0.000 * * *$ \\
\hline $\begin{array}{l}\text { Key Informants } \\
\quad(\mathrm{n}=9,9,18)\end{array}$ & 6.25 & 6.25 & 1.000 \\
\hline Groundwater & 5.80 & 6.42 & $0.014^{*}$ \\
\hline $\begin{array}{l}\text { Key Informants } \\
\quad(n=9,9,18)\end{array}$ & 5.13 & 7.04 & $0.018^{*}$ \\
\hline Minerals & 5.02 & 5.72 & $0.034 *$ \\
\hline $\begin{array}{l}\text { Key Informants } \\
\quad(n=9,9,18)\end{array}$ & 4.19 & 5.75 & 0.231 \\
\hline Plate Tectonics & 5.57 & 5.05 & $0.050 *$ \\
\hline $\begin{array}{l}\text { Key Informants } \\
\quad(\mathrm{n}=9,9,18)\end{array}$ & 5.75 & 4.13 & 0.071 \\
\hline Rivers-Flooding & 5.88 & 5.36 & $0.028^{*}$ \\
\hline $\begin{array}{l}\text { Key Informants } \\
\quad(\mathrm{n}=9,9,18)\end{array}$ & 6.00 & 6.19 & 0.853 \\
\hline Rocks-Rock Cycle & 6.09 & 5.48 & $0.036^{*}$ \\
\hline $\begin{array}{l}\text { Key Informants } \\
\quad(n=9,9,18)\end{array}$ & 5.19 & 5.69 & 0.615 \\
\hline Volcanoes & 5.37 & 4.57 & $0.002 * * *$ \\
\hline $\begin{array}{l}\text { Key Informants } \\
\quad(\mathrm{n}=9,9,18)\end{array}$ & 6.50 & 5.13 & 0.189 \\
\hline Weathering-Erosion & 5.83 & 5.65 & 0.533 \\
\hline $\begin{array}{l}\text { Key Informants } \\
\quad(\mathrm{n}=9,9,18)\end{array}$ & 4.94 & 6.00 & 0.192 \\
\hline
\end{tabular}

$\mathrm{A} *$ indicates $\mathrm{p}<0.05, \mathrm{a} * *$ indicates $\mathrm{p}<0.01, \mathrm{a} * * *$ indicates $\mathrm{p}<0.001$

Table shows means based on rank order of 10 topics.

The responses to these ranking items correlated to an open-ended response item that asked for participants enduring knowledge of geology (their primary take-away from the course) (Table 3a). Coded responses revealed the largest number of participants cited aspects of Dynamic Earth (related to tectonics, earthquakes, and volcanoes). Another open-ended response item that asked for participants' interpretation of geology's big picture or central theme (Table $3 b$ ) identified Process and Change (including references to long term events and cycles like plate tectonics) was the most common theme, while How the Earth Works/is Shaped (by tectonics) and Connectedness and Systems followed in their frequency of citation. Of note is participant response to enduring knowledge was the substantial shift between the fall and spring cohorts on the coded topic of Building Blocks (minerals and rocks). 
Table 3a. Frequency and percentages for enduring knowledge of geology

\begin{tabular}{ccc}
\hline Category & Fall $(\mathbf{n = 1 1 7 / 1 8 6})$ & Spring (n=109/147) \\
\hline Dynamic Earth (Tectonics, Earthquakes, Hazards) & $80(43 \%)$ & $53(36 \%)$ \\
\hline Time-Cycles-Changes & $8(4 \%)$ & $14(10 \%)$ \\
\hline Landforms-Structures & $7(4 \%)$ & $3(2 \%)$ \\
\hline Building Blocks (Minerals, Rocks, Identification) & $30(16 \%)$ & $55(37 \%)$ \\
\hline Earth's Surface (Erosion, Rivers, Glaciers) & $50(27 \%)$ & $13(9 \%)$ \\
\hline All/Some/Most of it-Basics & $11(6 \%)$ & $2(1 \%)$ \\
\hline Nothing/None of it & 0 & $7(5 \%)$ \\
\hline
\end{tabular}

Table 3b. Frequency and percentage for geology’s big picture

\begin{tabular}{ccc}
\hline Theme & Fall $(\mathbf{n = 1 2 1 / 1 6 4 )}$ & Spring $(\mathbf{n = 1 1 6 / 1 6 2})$ \\
\hline How Earth Works/Shaped & $25(15 \%)$ & $35(22 \%)$ \\
\hline Human Impact & $19(12 \%)$ & $24(15 \%)$ \\
\hline Processes/Change/Geologic Events-Tectonics & $18(12 \%)$ & $15(9 \%)$ \\
\hline Systems/Connectedness & $52(32 \%)$ & $51(31 \%)$ \\
\hline History & $24(14 \%)$ & $16(10 \%)$ \\
\hline Landforms/Features & $14(9 \%)$ & $14(9 \%)$ \\
\hline
\end{tabular}

The theme of Dynamic Earth became apparent again when participants ranked the lab activities that interested them the most and which benefited their understanding of geology (Table 4). The most significant positive shift in their responses was for the two labs on geologic time and plate tectonics. Key informants felt similarly strongly about the geologic time lab. Responses from two of the key informant interviews exemplified this.

“...that was interesting. And, you know, like, mid-ocean ridges. Like, wow, there's the giant split. There was that one lab we calculated how fast it separated. That was just super exciting for me, I thought. It was like, "Oh my gosh, this is..." you got to actually see the numbers, like, "This much."

"So, if there's volcanic rocks in our area, and there's no volcanoes around, then you can start to infer, "Well, how did these rocks get here? What could my area have looked like in the past?" And then, especially when we talked about geological time, and did that experiment up in the hallway and then had all the pictures and everything and realizing that we're just this itty bitty little part in the grand scheme of things. That was really amazing to me."

Table 4. Means and significance for rank order for lab interest benefitting understanding

\begin{tabular}{cccc}
\hline ITEM & Combined Pre $(\mathbf{n}=\mathbf{2 2 8})$ & Combined Post $(\mathbf{n}=\mathbf{2 2 8})$ & Combined Significance \\
Mineral/Rock Identification & 3.43 & 4.37 & $0.000^{* * * *}$ \\
Key Informants (n=9,9,18) & 3.13 & 3.88 & 0.237 \\
\hline Glacial Features-Climate Cycles & 3.05 & 3.19 & 0.269 \\
Key Informants (n=9,9,18) & 3.63 & 3.25 & 0.394 \\
\hline Earthquake Epicenters & 3.33 & 3.31 & 0.785 \\
Key Informants ( $=9,9,18)$ & 3.75 & 4.38 & 0.155 \\
\hline Modeling Geologic Time & 4.33 & 3.56 & $0.000^{* * *}$ \\
Key Informants ( $=9,9,18)$ & 4.13 & 2.69 & $0.012^{*}$ \\
\hline Plate Motions-Reconstructions & 4.26 & 3.93 & $0.014^{*}$ \\
Key Informants (n=9,9,18) & 4.31 & 4.06 & 0.580 \\
\hline Field Trip & 2.59 & 2.46 & 0.386 \\
Key Informants (n=9,9,18) & 2.06 & 2.35 & 0.151 \\
\hline
\end{tabular}

$\mathrm{A} *$ indicates $\mathrm{p}<0.05, \mathrm{a} * *$ indicates $\mathrm{p}<0.01, \mathrm{a} * * *$ indicates $\mathrm{p}<0.0 .001$ 
The most significant negative change in participant interest and understanding was the mineral and rock identification labs.

\subsection{Course Structure}

Participants were asked to provide an ideal syllabus sequence of topics, one that made logical sense to them in order to maximize their understanding of geology. Results for the combined cohort (Table 5) present the median and mode for each topic. The 10 topics listed were not necessarily covered in the introductory geology course the participants were taking, and were chosen based on their frequency appearing in the document analysis of external syllabi. The general sequence of the 10 topics appears to align with participants' views on geology's big picture and content appreciation, with geology's paradigms at the beginning (time and tectonics), followed by dynamic Earth events (volcanoes and earthquakes), followed by the building blocks (minerals and rocks), then the sculpting of Earth (weathering and erosion, rivers, groundwater and glaciers). Looking at the combined results produces a learning sequence as follows:

1. Geologic Time

2. Plate Tectonics

3. Volcanoes

4. Earthquakes

5. Minerals

6. Rocks-Rock Cycle

7. Weathering-Erosion

8. Rivers-Flooding

9. Groundwater

10. Glaciers

Table 5. Median and mode rank order for course sequence

\begin{tabular}{|c|c|c|}
\hline Item & $\begin{array}{c}\text { Combined } \\
\text { Median }(n=228)\end{array}$ & Combined Mode $(n=228)$ \\
\hline Earthquakes & 4 & 3 \\
\hline Key Informants & 4 & 4 \\
\hline Geologic Time & 1 & 1 \\
\hline Key Informants & 1 & 1 \\
\hline Glaciers & 8 & 10 \\
\hline Key Informants & 8 & 10 \\
\hline Groundwater & 9 & 9 \\
\hline Key Informants & 9 & 9 \\
\hline Minerals & 5 & 5 \\
\hline Key Informants & 5 & 5 \\
\hline Plate Tectonics & 2 & 2 \\
\hline Key Informants & 2 & 2 \\
\hline Rivers-Flooding & 7 & 8 \\
\hline Key Informants & 8 & 8 \\
\hline Rocks-Rock Cycle & 5 & 6 \\
\hline Key Informants & 5 & 6 \\
\hline Volcanoes & 4 & 4 \\
\hline Key Informants & 3 & 3 \\
\hline Weathering-Erosion & 7 & 7 \\
\hline Key Informants & 7 & 7 \\
\hline
\end{tabular}




\subsection{Course Content Wishlist}

Participants were given a list of six topics they would be most interested to learn more about and would include in a future version of the same course. The selection of the six topics were also based on the document analysis of syllabi. The topic Human Impact on Earth was the only topic which showed significant increase in interest by participants (Table 6). Other topics, Energy and Natural Resources and Climate Change did not show a significant change although key informants rated these more interesting of the other choices.

Table 6. Means and significance of rank order for additional topic of interest to the curriculum

\begin{tabular}{cccc}
\hline ITEM & $\begin{array}{c}\text { Combined Pre } \\
(\mathbf{n = 2 2 8})\end{array}$ & $\begin{array}{c}\text { Combined Post } \\
(\mathbf{n = 2 2 8})\end{array}$ & Combined Significance \\
Careers in Geology & 4.75 & 4.83 & 0.577 \\
Key Informants (n=18) & 4.00 & 4.65 & 0.214 \\
\hline Climate Change & 3.38 & 3.30 & 0.455 \\
Key Informants (n=18) & 4.00 & 3.53 & 0.368 \\
\hline Coastal Processes & 3.35 & 3.96 & $0.009^{* *}$ \\
Key Informants (n=18) & 4.12 & 4.53 & 0.150 \\
\hline Energy \& Nat. Resources & 3.02 & 2.89 & 0.244 \\
Key Informants (n=18) & 2.35 & 1.94 & 0.130 \\
\hline Human Impact on Earth & 3.01 & 2.30 & $0.000^{* * *}$ \\
Key Informants (n=18) & 3.00 & 2.53 & 0.227 \\
\hline Oceans-Ocean Floor & 3.49 & 3.73 & 0.051 \\
Key Informants (n=18) & 3.53 & 3.82 & 0.538 \\
\hline
\end{tabular}

$\mathrm{A} *$ indicates $\mathrm{p}<0.05, \mathrm{a} * *$ indicates $\mathrm{p}<0.01, \mathrm{a} * * *$ indicates $\mathrm{p}<0.001$

Asked to include a new lab based on their interests, participants chose from a list of five for the pre-survey, while the post-survey had the same five choices but included an additional option to take another field trip. The options given to the participants were based on the introductory geology syllabus document analysis. Participants clearly favored taking a second field trip (Table 7). Their comments reflect this.

...It was just interesting, because at (the park) - I run there a lot, actually—so when we went on that field trip, we talked about all the processes that happened, like the streams carving out the valley, I was like, "Oh, that's really interesting, and things." ..and...I understand — it's just cool to understand why things are the way they are.

...One of the things that comes to mind is when we took the field trip to Happy Hollow. Like going out and seeing, "Oh, okay, here's stream terrace. Here's big rocks. Here's angular rocks. Here's rounded rocks." So, it's nice to be able to see that in the landscape, rather than just in your "Here's an elevation map. It's supposed to be elevated - this is the high point, this is the low point." And then you get to go out there, and "Okay, now I can see where the high points are and where the low points are." I thought that was nice.

Creating simulated volcanic eruptions and studying past eruptions, working with the stream table to model river erosion and deposition, and building mini-glaciers and creating glacial landforms was consistently highly rated by the entire cohort and key informants. Yet, accessing real-time environmental data about water and rivers in their local watershed was consistently ranked low. 
Table 7. Median and mode rank order for participant preference and interest in new lab activity

\begin{tabular}{ccccc}
\hline & \multicolumn{2}{c}{ Combined Pre (n=228) } & \multicolumn{2}{c}{ Combined Post (n=228) } \\
& Median & Mode & Median & Mode \\
\hline Using Stream Table & 3 & 3 & 4 & 4 \\
\hline Key Informants & 3 & 2 & 3 & 3 \\
\hline Analyzing Maps & 4 & 4 & 4 & 6 \\
\hline Key Informants & 4 & 3 & 4 & 5 \\
\hline Erupting Volcanoes & 2 & 1 & 3 & 2 \\
\hline Key Informants & 2 & 2 & 4 & 4 \\
\hline $\begin{array}{c}\text { Making Glacial } \\
\text { Landforms }\end{array}$ & 2 & 1 & 3 & 2 \\
\hline Key Informants & 2 & 1 & 3 & 3 \\
\hline $\begin{array}{c}\text { Analyze Water } \\
\text { Quality Data }\end{array}$ & 5 & 5 & 5 & 6 \\
\hline Key Informants & 5 & 5 & 5 & 6 \\
\hline Take Another & & & & \\
Field Trip & na & na & 2 & 1 \\
\hline Key Informants & na & na & 1 & 1 \\
\hline
\end{tabular}

The participants were asked to identify how the course should be introduced the first day, selecting from among five topics and the option of "don't know." The options were again based on the syllabi document analysis. The most common response by the time of the post-survey was "What is geology and what do geologists do?" (Table 8). "How the Earth and solar system formed" (12-13\% fall, $16 \%-21 \%$ spring), and "A virtual trip from Earth's surface to the core" (22\%-22\% fall, $13 \%-15 \%$ spring) were the next two most chosen responses for opening day topics.

Table 8. Frequency and percentages for topic for the first day of class

\begin{tabular}{ccccc}
\hline Topic & \multicolumn{2}{c}{ Fall } & \multicolumn{2}{c}{ Spring } \\
& Pre (n=146) & Post (n=141) & Pre (n=140) & Post (n=124) \\
\hline $\begin{array}{c}\text { Scientific Method/ } \\
\text { Nature of Science }\end{array}$ & $14(10 \%)$ & $8(6 \%)$ & $12(8 \%)$ & $7(5 \%)$ \\
\hline $\begin{array}{c}\text { How the Earth/ } \\
\text { Solar System Formed }\end{array}$ & $18(12 \%)$ & $18(13 \%)$ & $23(16 \%)$ & $26(21 \%)$ \\
\hline $\begin{array}{c}\text { What is Geology and } \\
\text { What do Geologists do? }\end{array}$ & $62(42 \%)$ & $70(50 \%)$ & $68(48 \%)$ & $59(48 \%)$ \\
\hline Virtual Tour from Earth's Surface to the Core & $32(22 \%)$ & $32(22 \%)$ & $17(13 \%)$ & $19(15 \%)$ \\
\hline Don't Know & $20(14 \%)$ & $13(9 \%)$ & $20(14 \%)$ & $11(9 \%)$ \\
\hline
\end{tabular}

\section{Other Qualitative Results}

\subsection{Open-Ended Responses and Interviews}

When asked to cite the aspect of the lecture and lab that was most beneficial to their learning experience and understanding of geology, most participants $(n=105)$ cited the aspect of the class that dealt with their self-efficacy, accountability, and confirmation of understanding. Commonly cited examples referenced the regular use of classroom clickers, online homework modules, and the availability and access to lecture slideshows. The other common response 
honed in on students' preference for the visual/graphic aspects of learning (the slideshows, and any graphs, charts, and videos utilized during class time).

Certain content and skills were memorable to the key informants, as one informant emphasized the appeal of learning about the dynamic Earth, while another expressed her appreciation about learning to identify rocks:

...that whole section (on volcanoes and earthquakes) that we did in class was the most appealing thing.

...I was learning more, I was learning a lot...now I kind of can (identify a rock) and so I like that because I was really learning.

For the lab portion of the course, participants in both semesters most enjoyed the active and hands-on aspects of lab, including the oft-cited field trip. Learning about certain topics and practicing key skills was mentioned by participants in noting positive experiences with handling and interpreting rocks and minerals samples and working with maps. Collaboration and help from the teaching assistants contributed positive reinforcement to the participants' experience. The key informant cohort noted that their experience in lab was the best part of class and critical to their performance. Said one of the informants:

(the TA) did a great job...just being active was great...it was great and I really liked when we went to the park. That was really fun because we got...personal experience.

The extent of positive feelings toward the course and course experience did not depend on the key informant nor their science background as informants from both ends of this spectrum expressed enjoyment toward geology and learning geology. The negativity of memorizing rocks and minerals for tests and lab exams was conveyed throughout the interview process, as several key informants (13 of them mentioned it 39 times) expressed their dislike and frustration with this several examples of which were:

...Memorizing the names of rocks was pretty rough. Yeah, I didn't really enjoy that.

...All those labs were pretty...well...I didn't like that...it's just all that is that, there's no link. You have to memorize them one by one.

...The...really unappealing thing for me in this course was identifying the rocks...I don't know how I'll ever use that particular skill.

...There wasn't much to like about it (the material in the last third of the semester), I was like, what's the point? You know?

...Unlike rocks. It's just all—that is that. There's no link. You memorize them one by one...I hated that...all those labs were pretty-I didn't like that.

...The only really unappealing thing for me in this course was identifying the rocks...it wasn't really big picture enough for me to enjoy it.

The other aspect of the course that was not enjoyed was how the course was presented and delivered. Key informants, as well as the larger cohort of students in both semesters, were looking for assistance in their understanding and motivation to learn, and some of their comments also suggested changes to view this aspect more favorably.

...With the younger audience, us college students...it's less about the information. It's more about the presentation. The presenter has to make the information worthwhile to actually focus on...that was not done.

...Make it more engaging...I know the clickers were meant to make it more engaging but that's kind of debatable... actively engaging the class, asking for volunteers, and have demonstrations...

Similarly, the level of expectations, pace and difficulty of the class, given some participants limited science background, was also discussed.

...I just felt like I was handed a lot of things that weren't really related and didn't make me think about it later. So, when I got to the tests or something, nothing reminded me, like, "Oh yeah, this is what we did in lab, and that relates to this question." I just felt like I was handed a bunch of random stuff...I wasn't making the connection... felt like I would look at something and then it would be moving kind of fast, and I would be like, "Wait, what am I even looking at right now? What is this?

\section{Course and Lab Structure}

Because participants are drawing upon their own educational experiences, regardless of whether during secondary or university level, and their class standing, and the particular course, they have the ability to assess aspects of a course that are most meaningful to them, particularly when it comes to the instruction and delivery of content and activities. 
This experience and assessment can give insight into the attitudes toward this particular course and learning geology. Although some key informants expressed these opinions with positive outlook, there were several instances when they were distinctly skeptical of the manner in which aspects of the course were delivered and how the course would be a better environment for learning if their suggestions were heeded. The most common negative assessment was how quickly or slowly the instructor proceeded, and how connected (or not) the topics flowed from one to the next.

... I feel like the arrangement of topics was almost - I felt like they had the breakdown, but the stringing-That is where I thought there was a weakness. So, for instance, with the last section - the glacier section-I didn't really cling to that all, so much. Mostly because the topic was presented in a very kind of - more block fashion. You had the glaciers, and then the rivers, and then the waves. And what's really weird is I didn't see much content for waves in the exams, at all. Or the lab. We didn't talk about any of that. That was a weak one. Yeah. Like, "Glaciers, rivers, waves, go!

...I feel like it doesn't quite all connect as well as I would like it to be. So, I feel like it's lots of little courses, rather than one whole collective...I feel like it's really disconnected. And then, like, the beginning, it's specifically rocks and rocks moving. And then, all of a sudden, it's all of these other things that can affect rocks.

There was also concern about the level at which content was delivered, and the expectation that participants would have some level of background knowledge and be held to that standard through the semester.

I just felt like I was handed a lot of things that weren't really related and didn't make me think about it later. So, when I got to the tests or something, nothing reminded me, like, "Oh yeah, this is what we did in lab, and that relates to this question." I just felt like I was handed a bunch of random stuff.

...He kind of wanted us to be more geologists, rather than like, be learning it...I felt like they expected more out of us...(he) expected us to know a lot more than what we already did know.

I think a lot of the times in lecture or lab, it's like, "Well, these are the five different things that this whatever can do, and here they are really fast. Let's move on to the next thing...I felt like it moved quickly from one thing to another and I would have almost rather had one of the sections taken out and then have the whole course expanded a little bit more.

Ideas for improving the course structure focused infusing more active learning and less memorization, more visuals and demonstrations and student interaction into the lecture.

...Actively engaging the class-so, you know, asking for volunteers...And have demonstrations in class. I don't think any of the lectures had...something that's physically there, rather than someone talking at you with a screen that just kind of changes every two minutes.

...I think that would be really good to do (have break out small group discussion in class). Not only does it help break the tedium of the lecture. You know, it kind of wakes everyone up and gets them talking to each other. It kind of forces them to learn, because they'll be forced to talk to each other, and discuss what the teacher is saying. I think it helps with the learning.

...I prefer, for science classes, to work in groups. It would make me go, "Oh, okay, that makes sense. I never would have thought of it that way." So it gives me just a whole other perspective of how to go about the process.

...Why does this matter?” Especially if it's interesting to learn, you know. I guess that...always helps me...

...I think vocab was just a waste of time, honestly. Like, it's important to know what you're talking about...but...instead of identifying those...say, "Well, these are things that can happen," and then talk about what can we do to prevent that? Would you build a house here, based on these characteristics?...like use it in context. If you use it in context, sure I can figure it out like that. Most people could.

Despite experiencing some level of success in the course, exiting the course with newfound knowledge, and some level of appreciation for geology, participants, including the key informant cohort, seemed generally unmoved by the content and its potential impact on them or society as there was no defined aspect or topic that instigated any change.

...it's still the same. I mean, it didn't really change how I view everything together... all this time you just stop caring...I wasn't really interested any in them (topics)...I don't really think about the sciences most days. It's kind of, you know-I can't really pick out something that was super appealing that stuck out. Everything was on the same level of "Okay, it's what we're learning now. 
...I probably wouldn't care too much. But it definitely would raise more interest in what's going on here. But probably not enough for me to do any research or anything like that.

.... Nothing really comes to mind. Just any lab that changed my view of geology? I honestly don't know...I didn't really think too much about it. I was just kind of, going to get the credit, you know... I'm being honest, I'd say no, I don't think anything's really changed.

There was a definite feeling of being underwhelmed by the course, and as such, with little to affect positive change to participant attitudes and understanding of geology, the geologic blindness of the students remained, regardless of their academic performance and completion of the course.

\section{Discussion}

This study was aimed in part to unearth geologic blindness in undergraduate students taking an introductory geology course, and how their attitudes and perceived understanding of geology played a role in identifying that blindness. Based on the interpretation and integration of the quantitative and qualitative data regarding curriculum and instruction of an introductory geology course and its potential to impact student attitudes and perceived conceptual understanding, a few assertions arose and are described here to explain in context of the multiple data sources.

\section{Assertion: More interest $=$ less difficulty; less interest $=$ more difficult}

This assertion is based on participants' evaluation of their interest in course content and the relationship it has with participants' perception of their difficulty to learn and understand. It encompasses several key findings:

Participants indicated that the topics (tectonics, volcanoes, geologic time and rivers) deemed more interesting to learn about were also the same topics that they deemed less difficult to learn and understand. The reverse was also true for topics that the participants felt were less interesting being identified as the same that were more difficult to learn and understand.

Two of the course topics (geologic time and plate tectonics) that the participants considered more interesting and less difficult to understand corresponded to two of the labs that were judged more interesting to perform and which they learned the most from. The same topics were frequently cited in the open-ended responses as the participants' enduring knowledge of the course ("I will better understand the mechanics of plate tectonics," "the large timescale of Earth's history," and "(the continents) were once all together."). Participants placed geologic time and plate tectonics as the first two topics in their preferred course sequence. This may be due to their interest in the topic and better understanding of the topic they considered easier to comprehend. A better understanding of geologic time and plate tectonics may be central to understanding geology, and participants responded by placing them at the beginning of their preferred course sequence. This was reinforced in participants' open-ended responses about geology's big picture and their enduring knowledge from the course, as the terms processes and change, two terms often associated with geologic time and tectonics, were common themes in their responses.

Participants felt that geology's relevance to them, and the impact humans have on Earth should be explicitly taught throughout the course, so much so that Human Impact should be added to the curriculum as a distinct unit. They key informants echoes this idea, citing how the relevance and connectedness of topics and cycles that occur in geology play a role in their lives and needs to be reinforced in instruction.

\section{Assertion: Less memorization, and more active learning and visuals in lecture and lab.}

Participants indicated that the course should be taught so that it required less memorization of material without context and that more active learning and visual representations of geology and its processes, as well as collaborative and meaningful learning experiences.

Participants noted that memorization of rocks and minerals without context made the class and topic more difficult and less interesting to learn and understand. They also stressed that changes in the way the labs were taught and the format of the labs and lab exams needed to be made to de-emphasize memorization of minerals and rocks. Key informants also generally reflect this negative attitude toward memorization, citing not only how they were taught but also in the way they were assessed in lab and class.

Key informants frequently mentioned the value of the lab portion of the class and its hands-on component. Not only did they enjoy the active nature of lab, but its importance to their understanding content and how the material was relevant to their lives. Active and hands-on learning extended to lecture as well, as some key informants requested more student-instructor and student-student interaction. Participants, especially key informants, emphasized the importance of visualizations - the use of pictures, videos, and demonstrations - and their availability outside of class to reinforce concepts and understanding of the material. 
Participants and key informants seemed to favor the inclusion of a second field trip and more kinesthetic labs including working with volcanoes, glaciers, and a stream table. They stressed the application to the real world and usefulness of information to make decisions, using local examples, and interacting with geological material as important components driving their level of understanding and keeping their interest in the topic.

\section{Conclusions}

Geoscience instructors can and should have a minimum level of pedagogical content knowledge. They can and should deliver content and activities utilizing multiple modes of teaching. This may raise the students' level of understanding, awareness, and appreciation of geology, especially those who have limited science and geologic backgrounds and experiences. This is also an avenue for recruitment into a geoscience major. Consider energy, natural resources, mineral exploration, climate change, and natural disasters; these are challenges our society must face and meet and they are all within the venue of the geosciences. Geology is the meta-science that has the ability to investigate, understand, and pose solutions to these challenges. This needs to be explicit when teaching introductory students, as they may not see those connections or relevance. Geoscience instructors must guide students toward that using context and place-based examples, case studies, real-time data acquisition and analysis, and collaborative opportunities to discuss, analyze and solve problems.

What steps can we take in order to affect change among this population of students? And how can instructors help students to overcome geologic blindness that may be prevalent?

Recommendations evolved as result of the research assertions and based upon geoscience education literature.

1. Reduce or eliminate memorizing minerals and rocks from labs and exams.

We need to revisit and overhaul the way we teach minerals and rocks, as memorizing minerals and rocks has been at issue for some time (Rettke, 1974). Moving away from this trend in introductory geology classes does not seem to have gained traction. Memorizing specific minerals and rocks and being tested on their correct identification will most likely not lead to a deeper, richer understanding of rock classification, formation, and relationship to surrounding rock layers. I propose a more effective way to teach about minerals and rocks is to allow students time to self-classify and to recognize variations among rocks, as well as provide time for students to observe, describe and annotate pictures of rocks and rock layers. This could lead to improved understanding of rocks and the processes and interactions that they have with their environment. Memorizing rocks for a test does little to progress these students' appreciation and application of what geology is, but learning rocks and minerals in context may certainly advance that.

2. Geology is a visual and process-oriented discipline: allow students time with different visualizations.

The students who were a part of my research made it clear that different forms of visuals are necessary to increase motivation and focus in the class and stimulate the learning process. But these cannot be an isolated picture of a particular geologic feature. A pretty picture of a landscape or process is nice, but that is the entry point. Ask students to make a list of observations. Those lists can be discussed with the instructor, or amongst each other, allowing for collaborative learning. Also have the students generate a list of questions about the feature. These can also be answered during class time. Students self-annotating a visual or graphic in class is not only an excellent formative assessment piece, it allows the student to utilize their own notes to study from, and self-constructed knowledge can be better and longer remembered. With the advent of hand-held electronic devices, tablets, and laptops, students can even manipulate the visual to alter variables or conditions. This may allow the students to observe changes over spatial and temporal scales which normally cannot be observed due to the nature of geology. This also allows for formative assessment, to give assurance that students' learning is on track. The infusion of active learning throughout the semester may also allow for improved understanding and attitudes to learning.

3. Teach them explicitly and let them reflect: What is the human impact on Earth?

Geology consists of landforms and processes that are both grand and cataclysmic, and minute and imperceptible, at least until the tipping point is reached. The interplay of these processes and cycles is important for our introductory geology students to be aware of. They are principle to many of the issues facing society, and our understanding and expertise of geology and earth systems is integral to posing solutions to these problems. Human influence on these systems and processes and how the Earth returns its influence can and should be a component of introductory geology classes. Geology instructors must allow time for students to reflect on this explicit instruction, which can transition to a student-directed (and collaborative) reflective discussion on human impact. Perhaps if this is infused into these introductory geology courses, we increase the influence of these students becoming citizen scientists and better stewards of the Earth. This study is significant in that, 1) it utilized mixed-methods research with extensive qualitative data integration as a means to investigate the relationship between student affect and conceptual understanding in 
introductory geology, and 2) it examined the impact of course scope and sequence, student preference for the topics that encompass the scope and sequence, and the impact they had on student learning and understanding of geology, and their attitudes toward learning geology.

Examining specific topics, pedagogical techniques, and learning activities that may instigate and initiate attitudinal changes may be important to instructors who teach introductory classes. Although no two introductory classes are the same, specific topics, pedagogical techniques, and choice of learning activities are somewhat common across most introductory geology courses. This may encourage instructors to reflect on their approach to developing their course and syllabus and their teaching in these courses. It may also encourage students to be more aware of and appreciate their geological surroundings. The generalizability of the conclusions beyond the particular university and the course being studied is limited, particularly the qualitative component, because of the number of participants and length of time of study, and that the students sampled may not have similar characteristics to the overall population of undergraduate introductory geology students. Nonetheless, there may be much to learn from new or modified generalizations, which can be made to other cases even though this study is a single case in time.

Instructors of geology should be cognizant of geologic blindness as they begin teaching their courses. This insight can inform and improve the instruction and the curriculum. Exposure to geology by taking an introductory course may be the first step towards breaking down geologic blindness. Then, we need to examine and find consensus of the specific topics, the lab or classroom activities as well as variety of instructional techniques that instigate and initiate attitudinal changes in our students. While no two classes are the same, certain student-centered activities in lecture (even large lecture classes), and specific content topics taught at in meaningful sequence in the semester may encourage students to be more aware of their geological surroundings. It also allows instructors at specific institutions to provide a more place-based curriculum and syllabus, thereby helping to heighten student sensitivity toward geology. Teaching introductory geology students as if they were cardboard cutouts filling lecture halls and labs is not a flattering picture. Nor does it leave a positive impression of what geology is and how it can be a vital part of students' lives. I contend that attention and consideration to the selection and sequencing of topics, as well as to specific lab activities, can begin to diminish geologic blindness and allow students to better recognize the geologic world around them, and as a result, better stewards of this planet we call home.

\section{References}

Adams, W. K., Perkins, K. K., Podolefsky, N. S., Dubson, M., Finkelstein, N. D., \& Wieman, C. E. (2006). New instrument for measuring student beliefs about physics and learning physics: The Colorado Learning Attitudes about Science Survey. Physical Review Special Topics-Physics Education Research, 2(1), 010101. https://doi.org/10.1103/PhysRevSTPER.2.010101

Almberg, L. (2011). Pop Rocks! Engaging first-year geology students by deconstructing and correcting scientific misconceptions in popular culture. A practice report. The International Journal of the First Year in Higher Education, 2(2), 69-76. https://doi.org/10.5204/intjfyhe.v2i2.85

Atkin, S. A., Jorgensen C., \& Zeiler, K. G. (2005, October). An Earth Systems Approach for Fulfillment of Undergraduate Science Requirements for Non-Science Majors. In 2005 Salt Lake City Annual Meeting.

Baldwin, J. A., Ebert-May, D., \& Burns, D. J. (1999). The development of a college biology self-efficacy instrument for nonmajors. $\quad$ Science $\quad$ Education, $397-408$. https://doi.org/10.1002/(SICI)1098-237X(199907)83:4<397::AID-SCE1>3.0.CO;2-\#

Berry, S. J. (2013). Using active learning strategies to investigate student learning and attitudes in a large enrollment, introductory geology course. West Virginia University.

Blank, R. K., Langesen, D., \& Petermann, A. (2007). State indicators of science and mathematics education 2007. Washington, DC: Council of Chief State School Officers.

Creswell, J. W., \& Clark, V. L. P. (2007). Designing and conducting mixed methods research.

Dalgety, J., Coll, R. K., \& Jones, A. (2003). Development of chemistry attitudes and experiences questionnaire (CAEQ). Journal of Research in Science Teaching, 40(7), 649-668. https://doi.org/10.1002/tea.10103

Del Castello, M., \& Cooke, M. (2008). Watch faults grow before your very eyes in a deformational sandbox. Journal of Geoscience Education, 56(4), 324. https://doi.org/10.5408/1089-9995-56.4.324

DeLaughter, J. E., Stein, S., Stein, C. A., \& Bain, K. R. (1998). Preconceptions abound among students in an introductory earth science course. Eos, Transactions American Geophysical Union, 79(36), 429-432. https://doi.org/10.1029/98EO00325 
Douglas, K. A., \& Purzer, Ş. (2015). Validity: Meaning and Relevancy in Assessment for Engineering Education Research. Journal of Engineering Education, 104(2), 108-118. https://doi.org/10.1002/jee.20070

Durbin, J. M. (2002). The benefits of combining computer technology and traditional teaching methods in large enrollment geoscience classes. Journal of Geoscience Education, 50(1), 56-63. https://doi.org/10.5408/1089-9995-50.1.56

Eaton, T. T. (2009). Engaging students and evaluating learning progress using collaborative exams in introductory courses. Journal of Geoscience Education, 57(2), 113-120. https://doi.org/10.5408/1.3544241

Geoscience Concept Inventory. (2014). Retrieved from http://geoscienceconceptinventory.wikispaces.com/

Gilbert, L., Stempien, J., McConnell, D. A., Budd, D. A., van der Hoeven Kraft, K. J., Bykerk-Kauffman, A., ... Wirth, K. R. (2012). Not Just "Rocks for Jocks": Who Are Introductory Geology Students and Why Are They Here?. Journal of Geoscience Education, 60(4), 360-371. https://doi.org/10.5408/12-287.1

Goldsmith, D. W. (2011). A case-based curriculum for introductory geology. Journal of Geoscience Education, 59(3), 119-125. https://doi.org/10.5408/1.3604824

Greer, L., \& Heaney, P. J. (2004). Real-time analysis of student comprehension: An assessment of electronic student response technology in an introductory earth science course. Journal of Geoscience Education, 52, 345-351. https://doi.org/10.5408/1089-9995-52.4.345

Hammersley, L. C., Levine, R., Cornwell, K., Kusnick, J. E., \& Hausback, B. P. (2012). The Geology of Mexico: A quantitative evaluation of a course designed to increase the number of Hispanic students participating in the geosciences at California State University, Sacramento. Journal of Geoscience Education, 60(2), 189-198. https://doi.org/10.5408/11-243.1

Harris, M. T. (2002). Developing geoscience student-learning centered courses. Journal of Geoscience Education, 50(5), 515-523. https://doi.org/10.5408/1089-9995-50.5.515

Hippensteel, S. P., \& Schwimmer, R. (2004, November). Sequence of Introductory Physical Geology Topics: When Should Plate Tectonics Be Taught?. In 2004 Denver Annual Meeting.

Houlton, H., \& Ricci, J. (2015). Preparation and Importance of Geology Competencies. Geoscience Currents, 103. Retrieved from www.Americangeosciences.org/workforce

Jach, J., Cervato, C., \& Ridky, R. (2009). News Media Databases for Content Selection and Relevance in Introductory Geoscience Courses. Journal of College Science Teaching, 39(1), 34-37.

Johnson, J. K., \& Reynolds, S. J. (2005). Concept sketches-using student-and instructor-generated, annotated sketches for learning, teaching, and assessment in geology courses. Journal of Geoscience Education, 53(1), 85. https://doi.org/10.5408/1089-9995-53.1.85

Knierim, K., Turner, H., \& Davis, R. K. (2015). Two-Stage Exams Improve Student Learning in an Introductory Geology Course: Logistics, Attendance, and Grades. Journal of Geoscience Education, 63(2), 157-164. https://doi.org/10.5408/14-051.1

Lewis, E. B., \& Baker, D. R. (2010). A call for a new geoscience education research agenda. Journal of Research in Science Teaching, 47(2), 121-129.

Libarkin, J. C., Anderson, S. W., Deeds, D., \& Callen, B. (2006, October). Development of the geoscience concept inventory. In Proceedings of the National STEM Assessment Conference, Washington DC (pp. 148-158).

Mathison, C. I. (1989). Checklist for Content of Introductory Geology Courses. Journal of Geological Education, 37(1), 18-19. https://doi.org/10.5408/0022-1368-37.1.18

Mattietti, G. K., Peters, E. E., \& Verardo, S. (2009, December). Geoscience Education and Cognition Research at George Mason University. In AGU Fall Meeting Abstracts (Vol. 1, p. 05).

McConnell, D. A., Steer, D. N., Owens, K. D., Knott, J. R., Van Horn, S., Borowski, W., ... Heaney, P. J. (2006). Using conceptests to assess and improve student conceptual understanding in introductory geoscience courses. Journal of Geoscience Education, 54(1), 61. https://doi.org/10.5408/1089-9995-54.1.61

McNeal, K. S., Spry, J. M., Mitra, R., \& Tipton, J. L. (2014). Measuring Student Engagement, Knowledge, and Perceptions of Climate Change in an Introductory Environmental Geology Course. Journal of Geoscience Education, 62(4), 655-667. https://doi.org/10.5408/13-111.1 
Monet, J., \& Greene, T. (2012). Using Google Earth and Satellite Imagery to Foster Place-Based Teaching in an Introductory Physical Geology Course. Journal of Geoscience Education, 60(1), 10-20. https://doi.org/10.5408/10-203.1

Novak, G. M. (2011). Just-in-time teaching. New directions for teaching and learning, 2011(128), 63-73. https://doi.org/10.1002/tl.469

Pintrich, P. R. (1991). A manual for the use of the Motivated Strategies for Learning Questionnaire (MSLQ). https://doi.org/10.1037/t09161-000

Pun, A. (2010, November). Multiple Uses of Clickers Integrated into a Learning Activity Sequence in Introductory Geology. In 2010 GSA Denver Annual Meeting.

Rettke, R. C. (1974). An Introduction to Rocks and Minerals: A Non-Dogmatic Approach. Journal of Geological Education, 22(1), 29-31. https://doi.org/10.5408/0022-1368-22.1.29

Riggs, M. L., Warka, J., Babasa, B., Betancourt, R., \& Hooker, S. (1994). Development and validation of self-efficacy and outcome expectancy scales for job-related applications. Educational and Psychological Measurement, 54(3), 793-802. https://doi.org/10.1177/0013164494054003026

Schneekloth, L. H. (1989). 'where did you go?' 'The forest'. 'What did you see?' 'Nothing'. Children's Environments Quarterly, 6(1), 14-17.

Siegel, M. A., \& Ranney, M. A. (2003). Developing the changes in attitude about the relevance of science (CARS) questionnaire and assessing two high school science classes. Journal of Research in Science Teaching, 40(8), 757-775. https://doi.org/10.1002/tea.10110

Tunnicliffe, S. D. (2001). Talking about plants-comments of primary school groups looking at plant exhibits in a botanical garden. Journal of Biological Education, 36(1), 27-34. https://doi.org/10.1080/00219266.2001.9655792

Vanderlinden, D. W. (2007). Teaching the content and context of science: The effect of using historical narratives to teach the nature of science and science content in an undergraduate introductory geology course. ProQuest.

Wandersee, J. H., \& Schussler, E. E. (1999). Preventing plant blindness. The American Biology Teacher, 82-86. https://doi.org/10.2307/4450624

Wandersee, J. H., Clary, R. M., \& Guzman, S. M. (2006). A Writing Template for Probing Students' Botanical Sense of Place. The American Biology Teacher, 68(7), 419-422. https://doi.org/10.2307/4452030 